Journal of Southeast Asian

\title{
Book Review: The Latehomecomer by Kao Kalia Yang
}

Sarah Hansen

University of Minnesota, hanse230@umn.edu

Follow this and additional works at: https://docs.lib.purdue.edu/jsaaea

Part of the Asian American Studies Commons

\section{Recommended Citation}

Hansen, Sarah (2010) "Book Review: The Latehomecomer by Kao Kalia Yang," Journal of Southeast Asian American Education and Advancement. Vol. 5 : Iss. 1, Article 9.

DOI: $10.7771 / 2153-8999.1010$

Available at: https://docs.lib.purdue.edu/jsaaea/vol5/iss1/9

This document has been made available through Purdue e-Pubs, a service of the Purdue University Libraries. Please contact epubs@purdue.edu for additional information.

This is an Open Access journal. This means that it uses a funding model that does not charge readers or their institutions for access. Readers may freely read, download, copy, distribute, print, search, or link to the full texts of articles. This journal is covered under the CC BY-NC-ND license. 


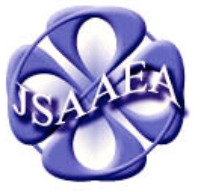

Volume 5 (2010)
Journal of Southeast Asian American

Education \& Advancement

WWw.JSAAEA.org
A peer-reviewed

scholarly journal

published by the

National Association

for the Education \&

Advancement of

Cambodian, Laotian,

and Vietnamese

Americans (NAFEA)

Yang, K. K. (2008). The Latehomecomer: A Hmong Family Memoir. Minneapolis, MN: Coffee House Press. 277 pp. $\$ 14.95$ (paperback). ISBN: 978-1-56689-208-7.

\author{
Reviewed by \\ Sarah Hansen \\ University of Minnesota
}

Before babies are born they live in the sky where they fly among the clouds. The sky is a happy place and calling babies down to earth is not an easy thing to do. From the sky, babies can see

the course of human lives. This is what the Hmong children of my generation are told by our mothers and fathers, by our grandmothers and grandfathers. They teach us that we have chosen our lives... From the sky, I would come again. -Kao Kalia Yang, The Latehomecomer

Yang situates readers in the clouds. The Latehomecomer, a memoir, invites us to peer down, to trace the course of many Hmong lives through the story of one family. It gives voice to memories of soul-sheltering mountains, fear-riddled jungles, body-swallowing rivers, vast oceans, and far-from-each other states in a new homeland. It is a testimony of survival, transition, and loss. But more than that, it is a story about love. Love between parents who "stick together in a hard life when they might each have an easier one apart" (p. 199). Love between aunts and uncles, brothers, sisters, and cousins. And love between Yang and her grandmother, the woman who first welcomed her from the sky. Through these relationships, Yang narrates the story of Hmong people before, during, and after the Secret War in Laos.

The book is organized into a prologue, four sections (each with three to four chapters), and an epilogue. The prologue outlines, in broad strokes, the places marking the course of Yang's life. We glimpse her as an infant and then as a child in the Ban Vinai Refugee Camp and the Phanat Nikhom Transition Camp in Thailand, and as child and later a young adult in Saint Paul, Minnesota. At the epicenter of each space is a question or a feeling about what it means to be Hmong. In Ban Vinai, Yang "learned that Hmong meant contained" (p. 1). In Phanat Nikhom, saying goodbye to family members and familiar landscapes recalled centuries of Hmong people leaving their homelands in search of freedom. Saint Paul, Minnesota, brought questions from others: "What is Hmong? Where is your country? What are you doing here in America? Are you ever going home again?" (p. 3). To readers looking over Yang's shoulder as she surveys U.S. books for chronicles of the Hmong experience, these questions begin to make sense, as we

\title{
@)
}

SOMERIGHISRESEREED Readers are free to copy, display, and distribute this article, as long as the work is attributed to the author(s) and the Journal of Southeast Asian American Education \& Advancement, it is distributed for noncommercial purposes only, and no alteration or transformation is made in the work. More details of this Creative Commons license are available at http://creativecommons.org/licenses/by-nc-nd/3.0/. All other uses must be approved by the author(s) or JSAAEA. 
realize along with Yang that accounts of Hmong people fighting alongside U.S. soldiers during the Vietnam War - and the atrocities that Hmong men, women, and children faced in Laos after the Americans departed - have largely gone untold. The Latehomecomer is, in part, a response to this historical omission. Indeed, a major contribution of this book is the work it does to reposition the lived experiences of Hmong people more centrally within the U.S. historical narrative.

Part I, "People of the Sky," takes readers to Laos in 1975. We see Yang's mother and father meet for the first time in the thickness of the jungle, both hiding with their families from Lao soldiers charged with exterminating the Hmong people. Shortly after marrying Yang's father, Yang's mother parts with her own mother for the last time. We see families torn asunder in ambush, life in an enemy camp, and the harrowing journey across the Mekong River. We see is not the best way to explain what readers experience in "People of the Sky;" however, we feel is better. When, for instance, Yang's mother secures her own mother's embroidery close to her heart before entering the Mekong so that she might find her way back to her mother after death, the reader (at least this reader) responds not academically, but emotionally. I cried when Yang's grandmother chose to cross the river with Yang's father-even though he did not have a raft like his brothers-because she wanted to die with her youngest son if he should not survive. When, after crossing the river, Yang's grandmother learns that one of her sons and his children have not made it to the shores of Thailand, I felt her visceral grief. My body shook with hers. Pain like this is intimate. The Latehomecomer, in an unprecedented way, allows readers in, invites us to feel the heaviness of the choices Yang's family - and countless other Hmong families - made in order to survive and love one another in a time of war. Some people will argue that vicariously experiencing memories of pain through reading texts produces temporary, fleeting, and superficial empathy. While readers, particularly readers who have not shared the experience of being a refugee, may never feel Yang's story to the depths that she does, the images and emotions she invokes are not fleeting. The Latehomecomer takes hold, burrows into hearts. It is a book that allows those of us who are not Hmong to grieve the fact that we have not known this story sooner and to share the weight of these memories now.

Rarely are the memories we are invited to share solely centered on sadness or fear. Rather, Yang does an excellent job of conveying the complexity of the human experience. For example, we feel vulnerability mixed with bravery and pride when Yang's mother resists the efforts of a Vietnamese soldier to carry her heavy pack on the way to an enemy camp. Even in a moment of heightened vulnerability, her mother protects her character. Many years later, Yang witnesses the vulnerability of her father when he tries to communicate in English to help find a restroom for his child in a busy airport. Yang notices that his voice loses its strength in English, but she is nonetheless extremely proud of the way he protects her. Similarly, in the Ban Vinai Refugee camp, there is hardship, but also joy. In fact, for Yang and her grandmother, "the life we had in the camp was ideal. We were surrounded by people who loved us" (p. 67). Without being didactic, The Latehomecomer reminds us that the human spirit is never one-dimensional, that people draw on their strengths even (especially) in trying times, and that caring relationships have the capacity to nurture us in powerful ways - to help us grow-even when forces beyond our control threaten our well-being.

Yang comes down from the clouds in Part II, "The Little Girl with the Dimples." In this section of the book, readers encounter the details of daily life first in Ban Vinai Refugee Camp and later in the Phanat Nikhom Transition Camp. We breathe in "green Parrot soap that smelled like Irish Spring with lots of flowers" (p. 83), "touch the muddy, black dirt, which was always 
waiting to take the clean away" (p. 64), and eat from the "white enamel-covered bowls, with little cracks where the metal peeked through" (p. 61). With poetic attention to particulars such as these, "The Little Girl with the Dimples" is a prime example of Yang's literary prowess. The style with which she examines the small details of her memories is also noteworthy. Sentences speak themselves in quiet tones that resemble human talk - the language of living stories. The effect feels effortless and beautiful. The Latehomecomer is worth reading for the aesthetic experience alone.

Part III describes "The American Years." Yang observes that being in the U.S. necessitates new ways of being in and moving through the world. She no longer skips; instead, adults hold her hand protectively, slowing her gate to a measured walk. In many ways, the U.S. feels constraining. Money (and its scarcity) becomes a central issue for the Yang family. Yang witnesses the adults in her life struggle to make ends meet. Significantly, finances create a barrier between Yang and her grandmother, who is resettled in California - a long distance from Minnesota. In Yang's words:

Money was like a person I had never known or a wall I had never breached before: it kept me away from my grandma. I saw no way to climb this wall. Sometimes I thought so much about money that I couldn't sleep. Money was not bills and coins or a check from welfare. In my imagination, it was much more: it was the nightmare that kept love apart in America. (p. 135)

Although Yang's family tries to focus on the positive aspects of living in the U.S., Yang notices that the American life her family had envisioned in the refugee camp fell far short of their expectations. In this way, The Latehomecomer speaks to a larger question that critical education scholar, Rita Verma (2008), has explored through her research with working class South Asian youth: What happens when globalized discursive flows create expectations about life in the United States that do not align with the socioeconomic realities of day to day survival? What are the affective consequences of living a dream that disappoints? What are the implications for understanding the experiences of immigrant and refugee students in socioeconomically diverse communities? These are becoming increasingly important issues for educational researchers working with youth in transnational contexts.

Indeed, The Latehomecomer raises important questions about how educational communities teach and learn with immigrant and refugee students in U.S. schools. Throughout her memoir, Yang's family persists in viewing school as a vehicle for socioeconomic mobility. Although readers sense the urgency with which Yang's parents encouraged their children to do well in school, less prominent in the text is an account of her parents' experiences helping their children to navigate the U.S. educational system. In a recent study illuminating newcomer Hmong parents' perceptions of their children's schooling experiences, Ngo, Bigelow, and Wahlstrom (2007) suggest participants often felt unable to fully advocate for their children in schools. They note, "A perceived major obstacle to parents' involvement was their lack of knowledge about the mechanisms of school and education in the U.S." (p. 27). Did Yang's parents feel frustrated by a similar lack of first-hand experience with U.S. schooling systems? Or did the social network they cultivated with their extended family members - several of whom had successfully completed their education in the U.S. - serve to mitigate this frustration? Research on Hmong parents' experiences in U.S. schools is still relatively limited (Ngo et al., 2007). The Latehomecomer suggests we need to know more. 
This call is all the more urgent given that Hmong American communities highly value education (e.g. Adler, 2004; Lamborn \& Moua, 2008; Lee, 2005), but nonetheless tend to fare less well academically than other Asian American groups (Lee \& Kumashiro, 2005; Ngo, 2006). Scholars contextualize this disparity by pointing to factors such as poverty and limited formal schooling opportunities that have tended to mark the Hmong refugee experience and their subsequent resettlement in the United States (Ngo, 2006, 2008). Hmong newcomer parents with limited experience navigating formal schooling institutions face barriers in partnering with teachers to promote their children's academic success (Lee, 2005; Ngo, 2008). Given the link researchers perceive between parental involvement and students' academic success (Arnold, Zeljo, Doctoroff, \& Oritz, 2008; Jeynes, 2007), Hmong parents' restricted participation as educational partners in schools is problematic and may partially explain the achievement gap between Hmong students and other Asian and Pacific Islander groups who do not share similar refugee experiences. For researchers concerned with educational equity, this is deeply troubling. By contributing in-depth empirical accounts of Hmong parents' and students' schooling experiences, qualitative researchers have an essential role to play in addressing these inequities. And as Yang suggests, via The Latehomecomer, so does memoir.

Here's why. Through memoir, authors speak their own stories. Scholar and social activist bell hooks has implored researchers to stop "talking about the 'Other"' (cited in Fine, 1994, p. 70, emphasis added). Through The Latehomecomer, Yang articulates, explains, and interprets her own experiences. Listening (instead of speaking), researcher-readers learn:

My cousin took Dawb and me to register [for school], but they didn't want us because we couldn't speak English well enough, and they didn't have the special teachers we would need. This is my first memory of feeling embarrassed. (p. 140-141)

Attending even more closely, we learn that "the life in school that opened before me made me feel old in a world that was struggling to be young. A silence grew inside of me because I couldn't say that it was sometimes sad to be Hmong, even in America (p. 151). Bitter embarrassment. Unspeakable sadness. These visceral insights are powerful because they represent what episodes were salient - not for an outside observer-but for Yang herself. In words she chooses, we learn what school was like as a Hmong newcomer in the United States. We see education through her eyes. By privileging the voices of immigrant and refugee writers who share their experiences through arts and literature, and by positioning these texts as important sources of information for understanding the lives of students, educational researchers have an opportunity to unsettle "colonizing discourse[s]" through our scholarship (Fine, 1994, p. 70). The Latehomecomer reminds us that our academic community needs more voices, more memoirs. It reminds us that creative work offers a different way to trace lives, a different way to listen.

Story takes center stage in Part IV ("The Latehomecomer") of Yang's memoir. In this section of the book, Yang describes how, as a young woman, she grew into a writer consumed by the need to share the stories held close to her family. She notes:

I began to realize how our lives in America would be our stories. I started to understand one of the many truths that governed life: by documenting our deaths, we were documenting our lives. The Hmong had died too many times, and each time, their deaths had gone unwritten. There were no testimonies. The witnesses grew old, and they died, 
and life continued, as they had never lived. I didn't want this to happen to my grandma, to this woman I adored, whom I could not imagine not loving forever. I wanted the world to know how it was to be Hmong long ago, how it was to be Hmong in America, how it was to die Hmong in America-because I knew our lives would not happen again. (p. 215)

This final section of Yang's memoir recounts stories Yang's grandmother tells about her own youth and also chronicles her spirit's journey back to her birthplace in Laos. In recounting the life journey of her grandmother, Yang bears witness to the life journeys of many Hmong men, women, and children. It is at once a family memoir and the memoir of a people. The Epilogue emphasizes the collective nature of the work. The memoir, as a whole, invites readers to share these memories, to consider the stories that have shaped so many lives. It is a literary work that rearticulates the American experience. Even more than this, however, The Latehomecomer urges educational research forward in important new directions. It deserves a prominent place on the bookshelves of scholars and activists committed to better understanding Hmong families' experiences in U.S. schools.

\section{References}

Adler, S. M. (2004). Home-school relations and the construction of racial and ethnic identity of Hmong elementary students. School Community Journal, 14(2), 57-75.

Arnold, D. H., Zeljo, A., Doctoroff, G. L., \& Ortiz, C. (2008). Parent involvement in preschool: Predictors and the relation of involvement to preliteracy development. School Psychology Review, 37(1), 74-90.

Fine, M. (1994). Working the hyphens: Reinventing self and other in qualitative research. In N. R. Denzin \& Y. S. Lincoln (Eds.), Handbook of qualitative research (pp. 70-82). Thousand Oaks, CA: Sage.

Jeynes, W. H. (2007). The relationship between parental involvement and urban secondary school student academic achievement: A meta-analysis. Urban Education, 42(1), 82-110.

Lamborn, S. D., \& Moua, M. (2008). Normative family interactions Hmong American adolescents' perceptions of their parents. Journal of Adolescent Research, 23(4), 411-437.

Lee, S. J. (2005). Up against whiteness: Race, school, and immigrant youth. New York: Teachers College Press.

Lee, S. J., \& Kumashiro, K. (2005). A report on the status of Asian Americans and Pacific Islanders in education: Beyond the "model minority" stereotype. Washington, DC: National Education Association.

Ngo, B. (2006). Learning from the margins: The education of Southeast and South Asian Americans in context. Race, Ethnicity and Education, 9(1), 51-65.

Ngo, B. (2008). The affective consequences of cultural capital: Feelings of powerlessness, gratitude and faith among Hmong refugee parents. Journal of Southeast Asian American Education \& Advancement, 3, 1-16. Retrieved from http://jsaaea.coehd.utsa.edu/index.php/JSAAEA/article/view/28/53

Ngo, B., Bigelow, M. \& Wahlstrom, K. L. (2007). The transition of Wat Tham Krabok Hmong children to Saint Paul Public Schools: Perspectives of teachers, principals, and Hmong parents. Hmong Studies Journal, 8. 1-35. 
Verma, R. (2008). Backlash: South Asian immigrant voices on the margins. Rotterdam: Sense Publishers.

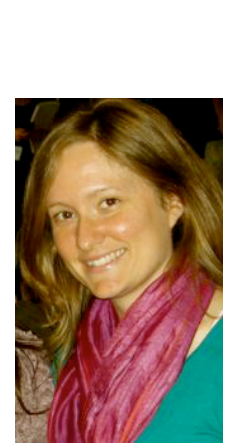

\section{About the Reviewer}

Sarah Hansen is a doctoral candidate in the Department of Curriculum and Instruction at the University of Minnesota. Her research examines the educational experiences of South Asian American students and parents. She is currently exploring how Indian youth in a co-ethnic community-based literature class make sense of the multiple discourses framing what it means to be South Asian in our present sociopolitical climate. Sarah's scholarship grows out of her experiences as a classroom teacher in local and international contexts. 


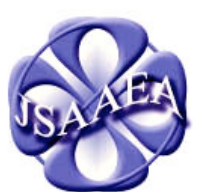

Volume 5 (2010)

\section{Journal of Southeast Asian American Education \& Advancement}

WWW.JSAAEA.org
A peer-reviewed scholarly journal published by the National Association for the Education \& Advancement of Cambodian, Laotian, and Vietnamese Americans (NAFEA)

\author{
Editor \\ Dr. Wayne E. Wright \\ University of Texas, San Antonio \\ Associate Editors \\ Dr. Chhany Sak-Humphry \\ University of Hawaii \\ Dr. KimOanh Nguyen-Lam \\ California State University, Long Beach \\ Book Review Editor \\ Dr. Vichet Chhuon \\ University of Minnesota \\ Creative Works Editor \\ Bryan Thao Worra \\ Lao Assistance Center \\ Special Advisor \\ Gregory Green \\ Curator, Echols Collection on Southeast Asia, Cornell University Library \\ Journal Manager \\ Sovicheth Boun \\ University of Texas, San Antonio
}

Comments and questions for the editorial staff may be directed to jsaaea@lists.sis.utsa.edu

\title{
Editorial Review Board
}

Dr. Carl L. Bankston III

Tulane University

Dr. Phala Chea

Lowell Public Schools

Dr. Loan Dao

Cancer Prevention Institute of California

Dr. Sophal Ear

U.S. Naval Postgraduate School

Dr. Samlong Inthaly

Minneapolis Public Schools

Dr. Kevin K. Kumashiro

University of Illinois, Chicago
Dr. Pollie Bith-Melander

Asian and Pacific Islander Wellness Center

Dr. George Chigas

University of Massachusetts, Lowell

Dr. Changming Duan

University of Missouri, Kansas City

Dr. Nancy H. Hornberger

University of Pennsylvania

Dr. Peter Nien-Chu Kiang

University of Massachusetts, Boston

Dr. Stacey Lee

University of Wisconsin, Madison 


Dr. David Chanpannha Ley
Montgomery County Public Schools
Dr. Bic Ngo
University of Minnesota
Dr. Leakhena Nou
California State University, Long Beach
Dr. Mark Pfeifer
Texas A\&M University, Corpus Christi
Dr. Bounlieng Phommasouvanh
Minnesota Department of Education
Dr. Kalyani Rai
University of Wisconsin, Milwaukee
Dr. Nancy J. Smith-Hefner
Boston University
Dr. Loan Tran
Center for Applied Linguistics
University of California, Riverside
Dr. Khatharya Um

\author{
Dr. Sue Needham \\ California State University, Dominguez Hills \\ Dr. Max Niedzwiecki \\ Daylight Consulting Group \\ Dr. Clara Park \\ California State University, Northridge \\ Dr. Loan T. Phan \\ University of New Hampshire \\ Dr. Karen Quintiliani \\ California State University, Long Beach \\ Dr. Fay Shin \\ California State University, Long Beach \\ Dr. Yer J. Thao \\ Portland State University \\ Dr. Myluong Tran \\ San Diego State University \\ Dr. Linda Trinh Vo \\ University of California, Irvine \\ Dr. Zha Blong Xiong \\ University of Minnesota
}

Dr. Kou Yang

California State University, Stanislaus

\section{Doctoral Student Editorial Review Board}

\author{
Keo Chea-Young \\ University of Pennsylvania \\ Peter Tan Keo \\ Columbia University \\ Ha Lam \\ Arizona State University \\ Monirith Ly \\ Texas State University-San Marcos \\ Malaphone Phommasa \\ University of California, Santa Barbara \\ Rassamichanh Souryasack \\ University of California, Santa Barbara \\ Layheng Ting \\ State University of New York, Albany \\ Tinou Tran \\ University of Houston, Texas \\ Phitsamay Sychitkokhong Uy \\ Harvard University
}

Annie BichLoan Duong

San Joaquin County Office of Education

Polinda Keo

University at Albany

Ravy Lao

University of California, Santa Barbara

Giang Pham

University of Minnesota

Vanna Som

Harvard University

Somongkol Teng

University of Minnesota

\author{
Alisia Tran \\ University of Minnesota \\ Silvy Un \\ University of Minnesota \\ Yang Sao Xiong \\ University of California, Los Angeles
}

